\title{
Upaya Pencegahan Anemia pada Remaja Putri
}

\author{
Julaecha \\ Prodi D III Kebidanan STIKBA Jambi \\ email: echa_mamee@yahoo.com
}

Submitted : 22/03/2020

Accepted: 09/04/2020

Published:16/06/2020

\begin{abstract}
Anemia is a micronutrient problem that occurs throughout the world especially in developing countries which is estimated to occur in $30 \%$ of the world's population. As a result of lack of hemoglobin levels causes symptoms of lethargy, fatigue and tired quickly when doing activities that will have an impact on decreased concentration and learning achievement, and in the long run it will have an impact on the quality of human resources, where young women are the future generation of the nation which will later supports determining the next generation. The results of basic health research in 2013 anemia in adolescent girls increased to 48.9\% in 2018. Data from the Health Office in Jambi City in 2017 as many as 257 adolescent girls who experienced anemia, increased to 404 people in 2018. The purpose of this community service is to provide information to adolescents about anemia and the importance of consuming blood-added tablets. The method used in this community service is lecture, question and answer discussion. This community service was held on February 13-14, 2019 at SMAN 8 Jambi City. The result of this community service is the increasing knowledge of young women about anemia and the benefits of consuming bloodadded tablets.
\end{abstract}

Keywords: anemia, knowledge, tablets added blood, teenager

\begin{abstract}
Abstrak
Anemia merupakan masalah gizi mikro yang banyak terjadi diseluruh dunia terutama dinegara berkembang yang diperkirakan terjadi pada $30 \%$ populasi penduduk dunia. Akibat dari kekurangan kadar hemoglobin menimbulkan gejala lesu, lemah letih dan cepat lelah saat melakukan aktifitas yang akan berdampak pada menurunnya konsentrasi serta prestasi belajar, dan pada jangka panjang akan berdampak pada kualitas sumber daya manusia, dimana remaja putri merupakan generasi masa depan bangsa yang nantinya akan mendukung menentukan generasi berikutnya. Hasil riset kesehatan dasar tahun 2013 anemia pada remaja putri meningkat menjadi 48,9\% pada tahun 2018. data dinas kesehatan Kota Jambi tahun 2017 sebanyak 257 orang remaja putri yang mengalami anemia, meningkat menjadi 404 orang pada tahun 2018. Tujuan pengabdian kepada masyarakat ini untuk memberikan informasi kepada remaja mengenai anemia dan pentingnya konsumsi tablet tambah darah. Metode yang digunakan dalam pengabdian masyarakat ini adalah ceramah, diskusi tanya jawab. Pengabdian masyarakat ini dilaksanakan pada tanggal 13-14 Februari 2019 di SMAN 8 Kota Jambi. Hasil dari pengabdian masyarakat ini adalah meningkatnya pengetahuan remaja putri tentang anemia dan manfaat konsumsi tablet tambah darah.
\end{abstract}

Kata Kunci: anemia, pengetahuan, remaja putrid, tablet tambah darah

\section{PENDAHULUAN}

Masyarakat Indonesia terutama wanita sebagian besar mengalami anemia hal ini dikarenakan kurangnya konsumsi sumber makanan yang mengandung zat besi yang mudah diserap oleh tubuh. Salah satu masalah yang dihadapi remaja Indonesia adalah masalah gizi mikronutrien, yakni sekitar $12 \%$ remaja laki-laki dan 23\% remaja perempuan mengalami anemia, yang sebagian besar diakibatkan kekurangan zat besi. (Kemenkes 2018)

Anemia di kalangan remaja perempuan lebih tinggi dibanding remaja laki-laki. Anemia pada remaja berdampak buruk terhadap penurunan imunitas, konsentrasi 
belajar, kebugaran dan produktifitas. Selain itu, secara khusus anemia yang dialami remaja putri akan berdampak lebih serius, mengingat mereka adalah para calon ibu yang akan hamil dan melahirkan seorang bayi, sehingga memperbesar risiko kematian ibu melahirkan bayi prematur dan berat bayi lahir rendah (BBLR). (Kemenkes RI 2014)

Menurut data hasil Riskedas tahun 2013 remaja putri mengalami anemia yaitu $37,1 \%$, mengalami peningkatan menjadi $48,9 \%$ pada Riskesdas 2018, dengan proporsi anemia ada di kelompok umur 1524 tahun dan 25-34 tahun. Hal ini jelas menguatkan bahwa kesehatan remaja sangat menentukan keberhasilan pembangunan kesehatan, terutama dalam upaya mencetak kualitas generasi penerus bangsa di masa depan. Hasil penelitian Isaati tahun 2014 prevalensi anemia remaja putri di Kota Jambi sebesar 78,7\%.

Faktor yang menyebabkan tingginya angka kejadian anemia pada remaja diantaranya rendahnya asupan zat besi dan zat gizi lainnya misalnya A,C, folat, riboflavin dan B12, kesalahan dalam konsumsi zat besi misalnya konsumsi zat besi bersamaan dengan zat lain yang dapat mengganggu penyerapan zat besi tersebut (Briawan, 2014).

Penanganan anemia yang bisa dilakukan adalah dengan pemberian tablet tambah darah $(\mathrm{Fe})$ awalnya program pemberian pemberian suplementasi besi direkomendasikan oleh World Health Organization (WHO) kepada ibu hamil, namun seiring berjalannya waktu sasaran program ditambah menjadi remaja putri. (kemenkes 2018)

Hasil penelitian Mariana dan Khafidhoh (2013) menunjukkan bahwa penyebab terjadinya anemia pada remaja dikarenakan pola makan yang tidak teratur, pantangan makan makanan berprotein, tidak suka mengkonsumsi sayuran, kebiasaan makan fast food dan junk food. Keadaan ini yang dapat menyebabkan remaja menjadi anemia selain itu penyebab anemia pada remaja status kesehatan yang kurang baik, status gizi, infeksi parasit dan pengetahuan yang kurang tentang anemia.

Demikian juga hasil penelitian Safitri dan Sri Maharani (2019), menunjukkan terdapat hubungan antara pengetahuan gizi terhadap kejadian anemia pada remaja putri di SMP Negeri 13 Kota Jambi. Sehingga dapat dikatakan bahwa remaja putri yang memiliki pengetahuan tentang gizi kurang baik akan mengalami anemia, dibandingkan mereka yang memiliki pengetahuan tentang gizi baik.

Kurangnya informasi dan pengetahuan remaja tentang anemia, maka perlu dan penting adanya pemberian informasi dan penyuluhan mengenai anemia sehingga dapat membuka wawasan remaja tentang anemia. Tujuan pengabdian masyarakat ini untuk memberikan informasi kepada remaja mengenai anemia dan pentingnya minum tablet zat besi dalam upaya pencegahan anemia pada remaja

\section{TARGET DAN LUARAN}

\section{Target}

Target yang diharapkan pada pengabdian masyarakat ini adalah

1) Meningkatnya pengetahuan remaja putri tentang anemia dan dampak anemia jangka pendek maupun panjang

2) Remaja putri mengetahui manfaat, efek samping dan dampak jika tidak mengkonsumsi tablet tambah darah $(\mathrm{Fe})$

3) Evaluasi program secara kontinyu

\section{Luaran}

Luaran dari pengabdian kepada masyarakat tentang upaya pencegahan anemia pada remaja adalah adanya kesepakatan bersama antara guru dan siswi untuk menentukan hari dan jam konsumsi tablet tambah darah dalam setiap minggunya

\section{METODE PELAKSANAAN}

Pelaksanaan kegiatan pengabdian kepada masyarakat dengan memberikan 
penyuluhan tentang upaya pencegahan anemia dan pentingnya konsumsi teblet tambah darah pada remaja putri kelas $\mathrm{X}$ dan XI di SMAN 8 Kota Jambi pada tanggal 13-14 Februari 2019. Metode yang digunakan dalam pengabdian kepada masyarakat ini adalah ceramah, diskusi tanya jawab. Media yang digunakan adalah leaflet.

\section{HASIL DAN PEMBAHASAN}

Kesadaran konsumsi tablet tambah darah $(\mathrm{Fe})$ saat menstruasi dan 1 tablet setiap minggu pada saat tidak menstruasi tidak lepas dari informasi dan pengetahuan, hal ini dikarenakan pengetahuan merupakan faktor yang mempengaruhi perilaku seseorang untuk konsumsi tablet tambah darah $(\mathrm{Fe})$

Hasil pengabdian kepada masyarakat mengenai pengetahuan remaja putri tentang anemia dan pentingnya konsumsi tablet tambah darah menunjukkan sebagian besar $60 \%$ remaja putri mengetahui tentang anemia dan $40 \%$ remaja putri kurang mengerti tentang efek samping dan manfaat teblet tambah darah dikarenakan belum pernah mendapatkan informasi tentang konsumsi tablet tambah darah pada saat menstruasi namun takut karena setelah minum tablet tambah darah jadi susah buang air besar, mual dan Tinja berwarna hitam.

Didukung oleh hasil penelitian yang dilakukan Martini (2015) menyatakan bahwa pengetahuan remaja yang kurang tentang anemia mempunyai resiko 2,3 kali mengalami anemia. Pengetahuan remaja yang kurang tentang anemia dapat mempengaruhi perilakunya termasuk pola hidup dan kebiasaan makan. Kurangnya pengetahuan tentang anemia menyebabkan kebutuhan zat besi didalam tubuh remaja akan kurang dan tidak mencukupi sehingga anemia dapat terjadi pada remaja

Sejalan dengan penelitian Wahyuningsih menyimpulkan bahwa kesadaran remaja dalam upaya pencegahan anemia melalui konsumsi tablet tambah darah masih rendah, terbukti dari servei anemia yang dilakukan pada 9 sekolah baik SMP maupun SMA hasil survei menunjukkan $2,67 \%$ siswi mengkonsumsi tablet tambah darah ketika sedang menstruasi. (Wahyuningsih 2008)

Anemia dapat dihindari dengan konsumsi makanan tinggi zat besi, asam folat, vitamin $\mathrm{A}$, vitamin $\mathrm{C}$ dan zink, dan pemberian tablet tambah darah (TTD). Pemerintah memiliki program rutin terkait pendistribusian TTD bagi wanita usia subur (WUS), termasuk remaja dan ibu hamil. Upaya pembinaan dan intervensi gizi oleh pemerintah secara bertahap dan berkesinambungan adalah dengan pemberian tablet tambah darah (TTD) bagi remaja putri dengan dosis pemberian 1 (satu) tablet perminggu yang betujuan untuk meminimalisasi remaja putri mengalami anemia.

Faktor lain yang mempengaruhi perilaku dan pengetahuan, konsumsi tablet tambah darah pada remaja juga dipengaruhi oleh kurangnya minat untuk mengkonsumsi tablet tambah darah saat menstruasi hal ini disebbakan karena individu merasa tidak sakit dan tidak memerlukan suplemen, efek samping yang ditimbuklan akibat konsumsi tablet tambah darah, rasa serta warna tablet tambah darah. (Arisman 2010)

Kesadaran konsumsi tablet tambah darah $(\mathrm{Fe})$ saat menstruasi tidak lepas dari informasi dan pengetahuan, hal ini dikarenakan pengetahuan merupakan faktor yang mempengaruhi perilaku konsumsi seseorang. Faktor yang mempengaruhi maslaah gizi pada remaja diantaranya pengetahuan, rendahnya pengetahuan tentang konsumsi berhubungan erat dengan konsumsi dan kesadaran dalam mencukupi gizi individu. Pada remaja putri perlu mempertahankan status gizi yang baik terbukti pada saat mentruasi terutama pada fase luteal terjadi peningkatan nutrisi, apabila hal ini diabaikan, maka dampaknya akan terjadi keluhan-keluhan yang 
menimbulkan rasa ketidaknyamanan selama siklus haid ( Irianto, 2014)

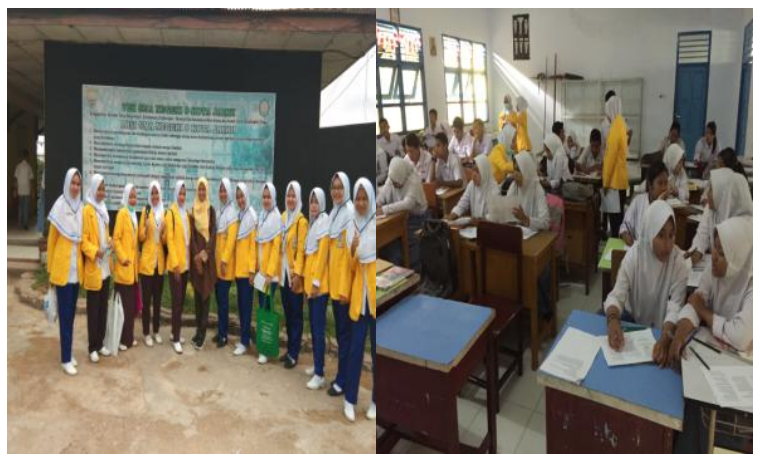

Gambar 1. Pelaksanaan kegiatan

\section{KESIMPULAN DAN SARAN}

\section{Kesimpulan}

Berdasarkan hasil dari pengabdian kepada masyarakat tentang upaya pencegahan anemia pada remaja putri, dapat disimpulkan bahwa terdapat peningkatan pemahaman remaja putri tentang anemia, manfaat dan efek samping jika tidak mengkonsumsi tablet tambah darah $(\mathrm{Fe})$ serta dampak jangka panjang dan jangka pendek apabila tidak mengkonsumsi tablet tambah darah.

\section{Saran}

Diharapkan pihak sekolah dapat meningkatkan peran dan fungsi UKS dengan membentuk teman sebaya, dan bagi tenaga kesehatan melakukan evaluasi dari penyuluhan-penyuluhan yang dilakukan sebelumnya untuk memantau kepatuhan siswi dalam mengkonsumsi tablet tambah darah, serta memberikan pemahaman dan motivasi tentang pentingnya konsumsi tablet tambah darah..

\section{UCAPAN TERIMAKASIH}

Terima kasih kepada Bapak Ketua Sekolah Tinggi Ilmu Kesehatan Baiturrahim Jambi yag telah memberikan dana dan Bapak Kepala Sekolah SMAN 8 Kota Jambi yang telah memberikan izin dan memfasilitasi kegiatan pengabdian masyarakat ini.

\section{DAFTAR PUSTAKA}

Arisman MB. Gizi dalam Daur Kehidupan Dalam Buku Ajar Ilmu Gizi. Jakarta: Penerbit Buku Kedokteran EGC: 2010

Briawan, D. 2014. Anemia. Masalah Gizi Pada Remaja Wanita. Jakarta : EGC

Irianto, K. 2014 Gizi Seimbang Dalam Kesehatan Reproduksi (Cetakan 1) Bandung. Alfabeta

Kemenkes RI, 2013. Riset Kesehatan Daerah tahun 2013. Jakarta

Kemenkes RI Kemenkes RI, 2014. Pusat Data dan Informasi Kementrian kesehatan RI“ Situasi Kesehatan reproduksi Remaja. Jakarta : Kemenkes RI

Mariana, W dan Khafidhoh, N. 2013. Hubungan Status gizi dengan kejadian anemia pada remaja putri di SMK Swadaya wilayah kerja puskesmas Karangdoro Kota Semarang. Jurnal kebidanan Vol. 2 No.4

Martini. 2015. Faktor-faktor yang berhubungan dengan kejadian anemia pada remaja putri di MAN 1 Metro. Jurnal kesehatan Metro sai Wawai. Vol. VIII No.1

RISKESDAS. Riset Kesehatan Dasar 2013. Jakarta: Badan Penelitian dan Pengembangan Kesehatan Kemenkes RI Tahun 2013

RISKESDAS. Riset Kesehatan Dasar 2018. Jakarta: Badan Penelitian dan Pengembangan Kesehatan Kemenkes RI Tahun 2018

Sukmadinata. Landasan Psikologi Proses Pendidikan Bandung, PT Remaja Rosdakarya 2013

Safitri, Sri Maharani, (2019). Hubungan Pengetahuan Gizi Terhadap Kejadian anemia Pada Remaja Putri Di SMP Negeri 13 Kota Jambi, Jurnal Akademika Baiturrahim Jambi Vol.8. No 2, September2019, Http://Jab.Stikba.Ac.Id/Index.Php/Jab/ Article/View 